\title{
Clio
}

Women, Gender, History

37 | 2013

When Medicine Meets Gender

\section{Crazy brains and the weaker sex: the British case (1860-1900)}

\section{Aude Fauvel}

Translator. Jane Yeoman

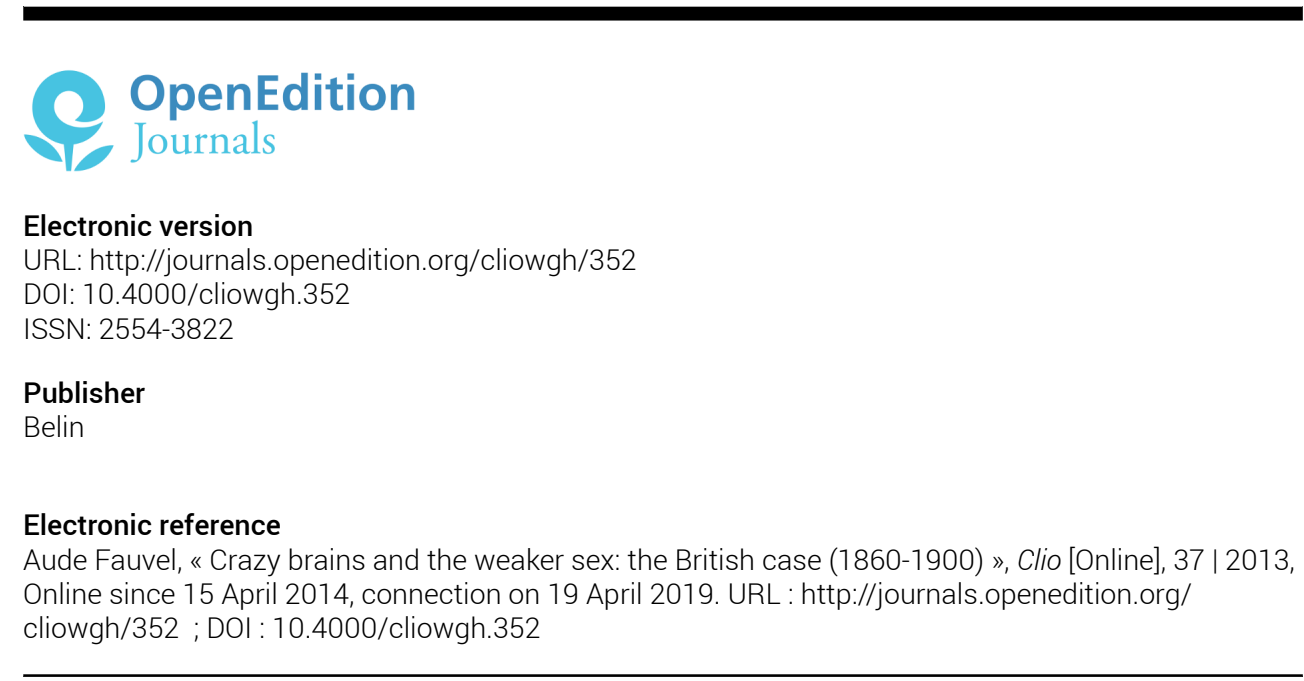

Clio 


\title{
Crazy Brains and the Weaker Sex: the British case (1860-1900)
}

\author{
Aude FAUVEL
}

In 1895, Henry Lanchester learned that his daughter Edith had fallen in love with a man who was not only poor, but also socialist and Irish; worse, she was intending to live with him out of wedlock. Thrown by the situation, Lanchester turned to the psychiatrist George Fielding Blandford", who decreed that Edith's "free love" was tantamount to "social suicide" and that his daughter could now be viewed as a "monomaniac" whose brain had been "turned by socialism" 2 . Lanchester was reassured. Edith was hospitalised "as a matter of ugency" - a radical means of curbing her tendencies towards revolt ${ }^{3}$.

This story, like many of its kind, serves to illustrate a classic thesis upheld by many women historians, ${ }^{4}$ that psychiatry probably qualifies as the sexist science par excellence. Psychiatrists not only nourished the discourse on the inferiority of the "weaker sex", they also literally contributed to the exclusion of women, by agreeing to hospitalise those who, like Edith, refused to bend to the wishes of men. Since the 1970s and the entry of feminist criticism into the human sciences,

1 George Fielding Blandford (1829-1911); see below for further bibliographical information.

2 Extract from a letter Blandford sent to the press in his own defence (Anonymous, 1895).

3 Lanchester 1983; Showalter 1987: 146-147.

4 Authorship in the field of psychiatric history is quite mixed, except with respect to the different treatment of the sexes, where almost all the work has been by women historians (Tomes 1994). 
writers from Phyllis Chesler ${ }^{5}$ to Lisa Appignanesi ${ }^{6}$, by way of Elaine Showalter ${ }^{7}$ have all stressed the biases of the 'mind sciences' ${ }^{8}$, an area where knowledge is actually very limited and thus all the more open to conventional opinion. Put differently, experts of the mind have had a troubling tendency to confuse a rejection of social conventions with mental illness. As a consequence, in the same way that homosexuals and dissidents (Communards, anti-Franco-ists, antiPutinists, etc.) have been viewed as "sick" and in need of "treatment", recalcitrant women have suffered the prejudices of a profession whose institutions were until relatively recently directed by men". The "mad-doctor" - he with the power to intern - was thus the same sex as the father, the brother or the husband. As a result, the psychiatric world was for a long time conducive to a kind of masculine connivance, with Edith's case (and hers is far from being the most dramatic ${ }^{10}$ ) clearly demonstrating how some men deliberately turned to psychiatric services in order to stifle the desires of their daughters, mothers or sisters.

The aim of this article is certainly not to question those observations regarding the frankly detestable role certain mindspecialists have played in the repression of women, but rather intends to reread that particular history from another angle, by considering, with reference to the British case ${ }^{11}$, how the taking of a sexist stance has played on doctor/patient interactions, altering the "knowledge" of the one and the discourse of the other. It is true that "psychiatric

5 Chesler 1975.

6 Appignanesi 2008.

7 Showalter 1987.

8 In French, les "sciences psys", an umbrella term often used to cover psychiatry, psychology, psychoanalysis, etc.

9 By way of example, the first woman to become Chief Medical Officer in an asylum in France only did so in 1920 (Constance Pascal in Prémontré).

10 As we will see, Edith Lanchester was finally released. Speaking more generally, we may note as illustration the fact that women were among other things, much more frequently lobotomised than men. (Showalter 1987).

11 As footnotes 16 and 19 explain, Scotland has its own independent Heath Service; nevertheless, since the debate over women extended over all British territory, we will use the term "Britain". 
power ${ }^{12 "}$ is often viewed as an indivisible whole, where all doctors always shared the same type of discourse relating to women and madness. Yet this was not the case: psychiatrists only started to theorise about the inferiority of the "feeble brain" and the idea that it was "natural" to intern more women, from the 1860s on, and even then, such beliefs were not unanimously held. Moreover, if writers have exaggerated the inflexibility of the medical profession, so, conversely, have they underestimated the capacity of patients, in particular women patients, to counteract the pronouncements of the doctors. And yet, to be specific (and here lies the whole interest of the example) if in the nineteenth century Britain was a country where psychiatrists pronounced the harshest words on the "weaker sex", it was also the setting for the first great feminist and anti-psychiatry triumphs - the one being profoundly nourished by the other.

How can this paradox be explained? What theoretical contorsions produced the idea of the "feeble brain" in the 19th century? And how did British women like Edith Lanchester manage to fight it? As we investigate these questions, we will take a different perspective on the relationships between psychiatry and (anti-)feminism, and question the mechanisms of construction (and deconstruction) of the categories of medical knowledge; we will also examine how the objects of this knowledge - women patients - managed to modify from "below" the theories and practices that concerned them.

\section{Women and the Female Mind under Psychiatry's Gaze}

Madness: from universal moral affliction to gendered degeneration

Contrary to what is sometimes claimed, the idea that madness was typically female did not appear in conjunction with early psychiatry ("mental treatment" or "alienism", to employ the 19th-century terms). The discipline's founding fathers believed that even if mental problems were undoubtedly linked to the physical, it was essential, when treating the mad, to remember that their troubles usually stemmed from a "moral" problem"13, such as bereavement,

12 Foucault: "Pouvoir Psychiatrique", 2003.

13 "Moral" is understood here as antonym to the physical (the physical and the moral). 
bankruptcy, or other kinds of severe shock. In consequence, it would suffice to administer a proportionately "moral treatment", in order to distract - in its strongest sense - patients from their affliction: either through a talking cure, or by providing them with healthy occupations and, most importantly, by isolating them in a secure medical environment (an asylum). From this point of view, the process leading to alienation (and to its cure) was seen as basically the same for both men and women. Certainly, psychiatrists thought that the reasons that caused the male or female of the species to become unbalanced might be different, as could the form of their madness. Women were more sensitive to the loss of a child, men to professional reversals; women often had religious obsessions, while men had political fantasies, etc. However, if the ways the two sexes manifested madness were different, there was nothing to indicate which was the more disposed to losing his/her mind. In consequence and contrary to what has been claimed ${ }^{14}$, in practice the first psychiatrists interned the same number of women as men, having detected the same levels of abnormality in the one as in the other ${ }^{15}$.

However, this situation changed dramatically in the second half of the nineteenth century, with a change in direction from the moral vision towards a much more physical sense of things - a change which came largely out of the disappointments encountered by psychiatry as early as the 1860s. Despite the optimism expressed by the field's pioneers, from that time on - some twenty years after the opening of public asylums here and there throughout Europe ${ }^{16}$ - it became clear that asylums were not "healing machines": success rates rarely exceeded $5 \%{ }^{17}$. Asylum patients did not get better, and more were admitted every day: in barely twenty years the number of psychiatric patients had multiplied ten times over, on both sides of

14 Chesler 1975; Showalter 1987: 3.

15 Tomes 1990; Fauvel 2010.

16 In France, a law of 1838 requireded that every 'département' take responsibility for all psychiatric patients within its boundaries by financing the relevant institutions (asylums). In England and Wales, a similar ruling was adopted in 1845, while Scotland had an independent system.

17 Scull 2004. 
the Channel, an exponential increase ${ }^{18}$ which rapidly put an end to initial hopes for the therapeutic control of madness.

Exactly what should contemporaries conclude from this? That there had been a mistake and that asylum-based treatment was perhaps not the correct moral response to insanity? Some alienists went precisely that far, and argued for research into other types of therapeutic care outside the asylums. However, with occasional exceptions ${ }^{19}$, they were not heeded; the majority of doctors preferred to find other explanations for the failure: if it was not possible to cure the insane, it was simply that their complaint was more serious than thought, and had doubtless profoundly affected not only the mind, but also the body. At the same time as Paul Broca and other neurologists were stressing the link between behavioural problems and brain injury, psychiatrists thus concluded that they too should further study the physiology of alienation. Moreover, in addition to the neurological discoveries, there was further backing for psychiatrists' change in attitude towards the somatic to be found in evolutionism. Had not Jean-Baptiste Lamarck and above all, Charles Darwin, shown that evolution was governed by heredity? It now seemed logical to postulate that those whom evolution had dealt a poor hand - the insane - conversely suffered from a hereditary defect. Or so concluded Henry Maudsley ${ }^{20}$ in Britain and Valentin Magnan $^{21}$ in France, who replaced the moral explanations with the

18 The numbers of those interned by the public sector in Britain grew from approximately ten thousand in the 1840 s to 50,000 in the $1860 \mathrm{~s}$, moving to almost 70,000 in 1871 and then to more than 100,000 in 1900 (Scull 2004): an evolution similar to that of France (Chapireau 2007, Fauvel 2010).

19 The Scots and the Belgians took distinctive approaches here, deciding to run large-scale tests based on following up the insane who were "at liberty" within small organisations such as host families. A century before the setting-up of similar activity in France, a third of Scottish patients were already benefiting from treatment outside institutions.

20 A brilliant orator, Henry Maudsley (1835-1918) was Professor of Medical Jurisprudence at University College, London, from 1869 to 1879. From 18661874, he directed a small mental health residence for women, Lawn House.

21 Valentin Magnan (1835-1916) was Medical Director of Admissions at SainteAnne's Hospital in Paris throughout his working life. 
term, 'degeneration'22. The impact of this theory was not quite the same on the two sides of the Channel, given Darwin's deeper imprint on British thinking. But in broad terms, these particular alienists postulated that when an individual damaged his or her body, by drinking too much alcohol, say, or through contracting a venereal disease, he or she would pass on the sequels to the children, who would consequently be born already "deficient" (the nineteenth century was aware of the principle of evolution, but not of the laws of genetics). Thus unless the process were to be blocked at the outset through anti-alcohol and venereal disease policies, or by dissuading the healthy from marrying "inheritors", medicine was left powerless. Once defects were acquired, they were indelible, a fact that led to the incurability of the majority of the insane; their bodies and brains were irremediably "injured".

As well as justifying the asylums' failures (if the alienated did not get better, it was not the doctors' fault, but because the patients were incurable), this doctrine of degeneration pushed psychiatry towards a more defeatist view of mental illness. Now the question was not so much to cure the mad but to protect the healthy: some even began to think that it would be best to sterilise (even to eliminate) the degenerate. But in addition to opening the way towards the eugenic strain of thought later seen in the twentieth-century interwar period, the spread of this theory provoked a further consequence. By placing the emphasis on somatic function, it triggered a marked sexualisation of psychiatric problems. For if the body were judged to be allimportant, thus enabling heredity and individuals' mental characteristics to be read in "stigmata", so men and women, with their dissimilar physiques, must also, logically, have different psychology.

\section{The weaker sex, sickly and insane}

In line with the logic of the new doctrine, alienists now set about establishing the boundaries of women's mental ability according to their physique, since the "best way to know the differences between the male and female intellect" was "to consider the differences that

22 Pick 1989. 
exist between their bodies" 23 . And given that the most obvious difference was to be found below the waist that was where the experts first focussed their attention. Those who believed in an unassailable bond between body and mind believed that the whole mystery of the female psyche was to be found precisely there, in the ovaries, uterus and vulva. British gynaecologists were also fully in agreement with this idea ${ }^{24}$ : they concluded that since treating a woman's lower abdomen was equal to treating her mind, they were the ones best placed to do so. Notably, they advocated the practice of sexual operations such as ovariectomy and clitoridectomy ${ }^{25}$, not to cure gynaecological problems but to treat troubles of the mind. In this situation, alienists now found themselves at risk of being overtaken by the gynaecologists, precisely because they themselves had insisted overly on the pubic region. Accordingly, they stressed a further point: it was not only the woman's reproductive organs that were different, but also their brains.

In Britain, James Crichton-Browne ${ }^{26}$, co-founder of the renowned journal, Brain, directly posed the question of the specificity of the female brain in 1879 in a celebrated study based on 400 dissected brains taken from the insane ${ }^{27}$. Crichton-Browne noted in particular a fact already observed by Broca in France: in humans, whether or not insane, men's brains were on average heavier than women's. From this, Crichton-Browne argued, two things could be deduced. Firstly, given that the human species was clearly at the peak of evolution, the difference in weight demonstrated that from every standpoint, cerebral included, females and males were destined to be different, the natural course of evolution showing a tendency to accentuate the characteristics of the sexes. He deduced in addition

23 Crichton-Browne 1892: 949.

24 Moscucci 1990; for an example of gynaecological analysis of mental problems: Barnes 1890.

25 Kingsley Kent 1990; Moscucci 1990; Oppenheim 1991; Sheehan 1997; Scull 2006.

26 Descendant of a family of Scottish doctors, James Crichton-Browne (1840-1938) was director of the Wakefield Asylum (1866-1875), then named Chief Inspector of the Asylum Service in 1876, a post he occupied for 45 years.

27 Crichton-Browne 1879. 
that since the size of cerebral mass indisputably (in his view) indicated intellectual strength, then women, who were known to have less muscle than men, were similarly disadvantaged in their powers of reason. Taken together, according to Crichton-Browne, these factors amply justified references to women as the "weaker sex".

Thus, in sum, evolutionary alienists believed that the possession of a uterus and a brain short of a few hundred grams defined the basic characteristics of a woman's body and in consequence, her psychology. Indeed, to follow their reasoning, since the sole purpose of the female sexual organs was to bear children (doctors considered that for women to find pleasure was of secondary importance, bordering on the pathological ${ }^{28}$ ) and that in addition the female brain was ill-suited to effort, then nature clearly destined women for one thing only: to be mothers. To remain healthy, it was enough for them to adhere to three rules: 1) protect their reproductive ability; 2) favour indoor occupations, their parenting nature disposing them towards creating homes; 3) avoid energetic activities which ran contrary to maternal gentleness.

To break any of these rules was considered, a contrario, an abuse of the fundamental nature of a woman's body and mind. Firstly, were a woman to indulge her senses (an act contrary to her nature), or, even worse, seek pleasure outside any reproductive goal (through protected sex, masturbation, lesbianism, etc.), her reproductive system would inevitably be deregulated, in which case it would be masculinised ${ }^{29}$ or overheated to the point of madness and/or death ${ }^{30}$. Marital continence was therefore demanded, while any encouragement of contraception or abortion was clearly quite unthinkable. Further, in the same way that a young woman's lower abdomen - particularly susceptible to acquiring unnatural practices at a transitional stage of maturity - had to be protected from temptation, it was also necessary to protect her other sensitive mental organ: her brain. Thus while

\footnotetext{
28 Maines 2009.

29 Nineteenth-century medical manuals churned out fantastic descriptions of the clitoris being enlarged by pleasure to penis-like proportions (Laqueur 2005).

30 In this manner, according to 19th-century doctors, nymphomania was "often" linked to the death of patients. (Fauvel 2012)
} 
educating girls to become good wives and mothers was seen as useful, it was seen as dangerous to submit them to intense intellectual stimulation, since their brains were not equipped to handle it, and that, moreover, they could not "...bear, without injury, an excessive mental drain as well as the natural physical drain..." 31 . Finally, it was thought that any such gentle and fragile creatures who dared practise a sport, or, worse, handle weapons, would almost inevitably succumb to dementia, so alien was the female body to such activity ${ }^{32}$.

Women who took the risk of living contrary to the "tyranny of their organisation" 33 would thereby suffer the inherent consequences, from simple fatigue to the most severe forms of madness. Any woman manifesting any such character traits (a lack of modesty, intellectual passion, etc.) was to be considered sick and in need of treatment, without which her own health and beyond that, the health of her species, would be compromised. According to the hereditary doctrine, those who were "deregulated" risked passing on their abnormalities - a danger made greater by the fact that "defects" were most easily transmitted from mother to child in utero. Within the framework of such medical reasoning, to wish that a woman vote, study or work at the same level as a man, became totally illogical. The "inferiority of constitution" of both body and mind of the "weaker sex" was a given piece of "physiological" 34 evidence which it would be absurd to deny. And above all, to work towards an artificial equality between men and women would imply a compromise both of the naturally differentiating evolution of the sexes and ultimately, of the future of the species. Would-be reformers were warned: to enable women to become more like men would lead, at best, to a society of "sexless" 35 individuals, similar to that of ants, and at worst to a generalised degeneration of humanity, dragged down by female "vampires" 36.

\footnotetext{
31 Maudsley 1874: 466-467.

32 Vertinsky 1990.

33 Maudsley 1874: 468.

34 Maudsley 1874: 479.

35 Maudsley 1874: 477.

36 Mitchell, cited by Scull (Scull 2009: 99).
} 
Rise and fall of a theory

Many authors have stressed the ruthless nature of this reasoning which relied on so-called "physiological truth" 37 , not only to justify a certain Victorian society's expectations of women's propriety, but also actively helped promote the repression of non-conformists by encouraging husbands to hospitalise all those who behaved in a manner "contrary to nature", in the name of protecting the evolutionary process. Although it was not the only factor, it was perhaps this encouragement which in part explains the statisticallynoted tendency to lock up greater numbers of women towards the end of the nineteenth century ${ }^{38}$. The effect of the message was the more devastating in Britain in that it was borne by some of the most renowned names in psychiatry. George Fielding Blandford, mentioned earlier, felt that any "amoral" idea signalled madness 39 , thus justifying the confinement of women such as Edith Lanchester precisely because they contested the validity of conformity to convention. Furthermore, in 1877, Blandford was President of nothing less than the Medico-Psychological Association (M-PA, the professional association of British alienists) - a title which alone demonstrates his renown. But no doubt the purest line of psychiatric evolutionism is seen in two other persons, also earlier named: Henry Maudsley and John Crichton-Browne are certainly the most famous British alienists to have defended the weaker sex thesis. Maudsley and Crichton-Browne were not only close to Darwin, the principal figure in the field of evolutionist thought, but were themselves prominent members of the intelligentsia of the age: Maudsley's lectures at University College were always packed, while Crichton was a leading contributor to the journal Brain. When we consider that in addition, these two doctors were elected to head up the M-PA (in

37 Maudsley 1874: 479.

38 In the inter-war period, some asylums admitted up to $30 \%$ more women than men (Chesler, 1975, Chapireau 2007). This tendency has reversed, with more men being hospitalised at the present time in closed institutions.

39 Blandford is known for his concept of "moral insanity": the notion that even if rational, anyone who defended amoral ideas could be considered as sick. 
1871 and 1886), it may be understood, without entering into their full career details, to what extent they shone in the medical world.

There is little doubt, then, that both Maudsley and CrichtonBrowne's opinions as experts had a significant impact, the more so since their views reached both the scientific world and the wider public. Among many examples of their influence, we see that in 1878, the decision of the British Medical Association (BMA, the association of general practitioners) to refuse women was founded on the ideas of the two men, with objections being raised about the ability of the female psyche to withstand the profession's exigencies. Or perhaps yet more significant, when in 1884 the authorities sought to evaluate reforms to be undertaken in London schools, they decided to consult a specialist in cerebral development and turned to none other than Crichton-Browne. Naturally, Crichton-Browne took full advantage of the situation to warn of the impact that women's schools would have on girls' health ${ }^{40}$. All things together, it seems certain that by the end of the nineteenth century, both the medical and general British authorities had been convinced of the infirmity of the female mind.

Nevertheless, looking more closely at this seeming success of the notion of the weaker brain, we see that the moment of triumph in Great Britain was actually very short-lived; some fifteen years after being validated by the scientific profession, the theory was, if not disproved, at least put aside. Thus while the date of women doctors' exclusion (1878) is always cited as proof of the reign of British medical misogyny, the moment in 1893 when the BMA reversed its decision, now not only accepting women, but even encouraging them, is often forgotten. Crichton-Browne himself had sensed something of this wind change one year earlier: he had again stressed the limits of the female brain in a paper delivered at the 110th Congress of the Medical Society of London (later published in the British Medical Journal ${ }^{41}$ ), but on this occasion, to his great surprise, the

$40 \quad$ Crichton-Browne 1884.
41 Crichton-Browne 1892. 
eminent doctor found himself harshly attacked ${ }^{42}$. And again, when in 1894 his own alienist colleagues from the M-PA were to vote in their turn, they aligned themselves with public opinion and admitted women after very little debate. Without going so far as to say that in Britain in 1894, no doctor still believed in the mental inferiority of women (this was far from being the case), these votes nonetheless clearly showed that such a thesis had lost its consensual aspect. As for Maudsley, he too realised that things had changed: at about this time, a disappointed man, he ceased to frequent British medical circles, their institutional choices having constituted an implicit rejection of his theoretical position.

\section{Psychiatrists as Seen by Women}

\section{Patients versus medical authority}

Just as historians have largely focussed on deciphering the way theories of female inferiority managed to permeate all scientific, public and private areas (to a point where women came to convince themselves of their own inferiority - the ultimate symptom of alienation) so they have similarly devoted little attention to the inverse process, which led, on the contrary, to the loosening of those theories' hold. More specifically, we may ask what happened between the years 1870 to 1890 that prompted certain doctors to distance themselves from these ideas in the way they did? The fact was that, in Britain, unlike elsewhere, the theories prompted both a strong and organised reaction on the part of patients, a phenomenon which was by no means the sole cause of their rejection, but was certainly a significant contributory factor. Historians have already described the importance of the waves of protest that followed the 1864 Contagious Diseases Act ${ }^{43}$. Effectively, this enabled the police to arrest women they judged to be prostitutes and authorised doctors to

42 The debate became prolonged in the BMJ between May and July. Notably, Crichton-Browne was challenged for not having taken women's smaller build into account in calculating the ratio of men's/women's brain matter and for not having considered the influence of social factors on women's nervous fragility.

43 Walkowitz 1980; Kent 1990. 
then forcibly examine them and to hold them in custody for as long as they saw fit; male clients, for their part, incurred no penalty whatsoever. The Act was to incite an unprecedented wave of anger against the medical profession, with some people, mostly women ${ }^{44}$, organising pressure to revoke it and to discredit the unhealthy tendencies which lay, as they saw it, behind its instigation. Had the Act been passed in order to limit the threat of venereal disease, these sceptics argued, doctors would have also targeted men ${ }^{45}$. If they attacked only women, it was undoubtedly because they were not so much concerned with health, but with an "unbridled medical desire to manipulate and dominate women" ${ }^{46}$. The campaign also incited woman patients to make themselves heard, thus revealing the magnitude of their discontent and notably providing an occasion for some to speak of doctors' excessive taste for examinations of a questionable nature ${ }^{47}$. The role of this struggle in the constitution of feminist thinking in Britain is quite well known, but its link to another important battle has been little explored - and for a reason: who could have imagined that one of women's greatest victories would have been won against psychiatrists, surely the ne plus ultra of all medical authorities?

Influenced by the image of an overwhelmingly strong "psychiatric power", historiography has generally viewed the nineteenth century as the one where the voice of the insane was crushed, being suppressed by doctors and confined to asylums. Consequently, when instances of the insane managing to make themselves publicly heard despite all the odds have been uncovered, they have been viewed as remarkable exceptions of "survivors" 48 and been studied case by case, without the possibility of the existence of a collective counter-culture among

44 Notably Josephine Butler (1828-1906) and Elizabeth Wolstenholme-Elmy (18331918), in the Ladies' Association Against the Contagious Diseases Act, founded in 1869.

45 Butler 1896.

46 Wilkinson 1870: 15.

47 Kent 1990: 127-135.

48 The word is employed for example in the bibliography of testimony from patients compiled by Gail Hornstein (Hornstein 2011). 
the insane ever having been evoked ${ }^{49}$. Yet it is not by chance that publications by 'invalids' have been more abundant at certain times and in certain places: it turns out that patients' silence has in fact been relative, Foucault's analysis in this instance applying more strongly to France than to Great Britain. English law automatically provides the right of appeal to habeas corpus and to be heard by the judiciary. And precisely this procedure, customarily rare, was used by those labelled insane to bypass the silence of the asylum, and was so often and ably employed that in order to avoid its occurrence, in 1845 the authorities actually instituted committees of laymen charged with hearing patients' complaints, without doctors having the right to oppose the measure $^{50}$. As a result of these legislative particularities, British people were more accustomed to hearing the voices of patients than was the case elsewhere; this doubtless explains why it was also in Britain that the very first association of psychiatric patients was founded: as early as $1845^{51}$ it sought to affect political policy (similar societies did not appear in France until the 1970s). Given that context, it is not surprising that when alienists began to take a particular interest in the weaker sex, a second association appeared: the Lunacy Law Reform Association was started by Louisa Lowe in 187452. It is therefore with Lowe and her associates that the first signs of a women's enterprise of deconstruction of psychiatric discourse are to be found - much more than with hysterics, in whom some writers have preferred to see unexpected resisters to medical authority ${ }^{53}$. For not only did these "mad women" start to speak up,

49 Fauvel 2005.

50 Mellett 1981.

51 Created by John Perceval (1803-1876), The Alleged Lunatics' Friend Society operated from 1845 to 1863 (Hervey 1986).

52 Although the name of Louisa Lowe is known to historians (Bennett, Nicholson \& Porter 2003; Owen 1989; Bland 1995), this association has yet to be studied in detail. We thus do not know how many members it had, nor the composition of its membership, although its first report shows that it attracted mainly women (Lowe 1874).

53 On the idea that the hysteric transposed her revolt against masculine and medical authority into the body by way of her pains and convulsions see Cixous \& Clément 1975, Foucault 2003. The thesis has been much criticised by 
but they even won their case, with Parliament finishing by amending the Asylum Law according to the women's recommendations, as we shall see.

\section{On the incompetence and stupidity of male doctors}

Whether gynaecologists or psychiatrists, those British doctors who were the most deeply convinced of the debility of the weaker sex thus came up against the opposition of women, who counter-attacked on three different fronts. Firstly from within the associations, activists fought to make cases of medical abuse known. We have already mentioned witness statements regarding inappropriate gynaecological examinations during the campaign against the 1864 law; in similar vein, the tabloid press and sometimes very well known editors such as John Lane ${ }^{54}$, also set about communicating the stories of women who had had experiences with the professionals of the mind. Both Louisa Lowe and Georgina Weldon ${ }^{55}$, the most famous recruit in her association, publicised the horrific accounts of their encounters with psychiatry in books ${ }^{56}$ and articles and through lectures and publicity tours; indeed, Weldon finished by generating a considerable income through her anti-alienist activities ${ }^{57}$. And to return to Edith Lanchester, with whom we introduced this article, she for her part turned to her socialist friends, who alerted the press and organised demonstrations on her account ${ }^{58}$. Moreover, following the example

English/US writers: Showalter 1987; Caminero-Santangelo 1998. For a summary of the debate, see Tomes 1994.

54 A politically active editor, John Lane (1854-1925) had great influence on the avant-garde. He enabled publication of The Yellow Book and also Professor Hieronimus (Skram 1899), a work written inside an asylum by the Norwegian novelist, Amalie Skram (1846-1905).

55 A music-lover, teacher and militant spiritualist, Georgina Weldon (1837-1914), having succeeded in escaping from the confinement requested by her husband in 1878 , spent the rest of her life battling against the collusion between doctors and husbands.

56 Lowe 1883; Weldon 1882.

57 Owen 1989; Walkowitz 1992; Bennett, Nicholson \& Porter 2003.

58 Lanchester 1983; Owen 1989; Bland 1995. 
of the novelist Charles Reade ${ }^{59}$, a close friend of Louisa Lowe, these women knew exactly how to play on British taste for the gothic and stories of mad scientists. It was through recounting terrifying anecdotes and playing the role of martyrs to an unnatural male science that women managed to attract public attention and shatter the myth of medical impartiality.

In addition to these rather sensational types of campaign, patients played a more positive role by voicing their opinions about what could constitute good mental heath treatment for women. While psychiatrists and gynaecologists stressed the role of physiology, women instead signalled the importance of social factors in the emergence of female insanity. They declared that it was not so much menstruation, heredity, or the size of the brain that explained why women were frequently subject to nervous problems, but rather the expectations of society. Pulled between the reality of their desires and the restraints imposed by society, women lived in a state of constant tension and were in consequence more likely to crack. In that context, doctors were of no help whatsoever: by declaring the social inferiority of women to be natural in origin, they contributed at best inappropriate therapeutic treatment and at worst, reinforcement of the collective hypocrisy, through assisting with the subjugation of recalcitrants: sexual operations, confinement and "rest-cures ${ }^{60}$ " indeed acted more as punishments than veritable treatments. To remedy the problem, it was thus necessary to ensure a stricter surveillance of doctors (hence the campaigns to change venereal and asylum legislation), achieved by listening more carefully to female patients and ultimately, through the feminisation of the medical profession, given that only a women could understand another woman. As to the question of whether the female body was so weak as to need the care of a guardian, some chose to respond with

59 Charles Reade (1814-1884) was among other things the author of Hard Cash (1863), the history of arbitrary confinement, a work that was republished seven times up until 1914.

60 The "rest-cure" is associated with the American, Weir Mitchell (1829-1914). It consisted of forcing women who were "intellectually exhausted" to follow a weight-gaining diet over several weeks with enforced rest. One woman to be submitted to the treatment was Virginia Woolf. 
humour. For after all, as the wife of one Winston Churchill remarked, if women were so completely handicapped, why did doctors not simply suggest they be "abolished"? 61

Lastly, the most efficient way to challenge psychiatric theories was to disprove them in practice, and demonstrate that women could undertake unnatural activities without degenerating or triggering an explosion of the brain. In consequence, most women patients who were critical of psychiatry were also fervent partisans of women's education and economic independence; Weldon herself directed a school and at every chance presented herself as living example of a woman's ability to live life on her own, in good health and without supervision by a husband. More generally, doctors' views on female fragility also had the paradoxical effect of pushing many women towards taking up studying (in particular, the study of medicine), in order to prove the opposite was true. Sophia Jex-Blake and Elizabeth Blackwell ${ }^{62}$ admitted that their commitment to a medical career had been primarily to fight against the "misdeeds" of male doctors, rather than out of true interest in medicine ${ }^{63}$. As for Mary Corinna Putnam $\mathrm{Jacobi}^{64}$, the first ever British woman to become a doctor (having exiled herself in France in order to so do), it was not by chance that she subsequently chose to practise psychiatry. In doing so, she was able to fight the discipline's prejudices as an expert on the inside, while leaning on the words and experience of one particularly well known patient: Charlotte Perkins Gilman ${ }^{65}$.

61 C.S.C. (Churchill) 1912, in response to an article by Almroth Wright (Wright 1912).

62 Sophia Jex-Blake and Elizabeth Blackwell belonged to the "group of seven" the first women to have attempted to enrol together in a British university (Edinburgh). Following their ultimate rejection, Jex-Blake opened a medical school for women in London in 1874.

63 Kent 1990: 131-132.

64 Born in London, Mary Corinna Putnam Jacobi (1842-1906) lived in the United States before returning to Britain, then moving to Paris, where she gained her medical doctorate in 1871. She then returned to America.

65 The American, Charlotte Perkins Gilman (1860-1935), is famous for having shown through a book (Gilman 1892) how the "rest-cure" could in actual fact 


\section{Towards a different version of female psychology?}

Faced with such a wave of contestation, doctors' responses swung initially between condescendence and frank hostility. Those women students who forced open the doors of British universities found themselves being insulted and sometimes even subject to abuse. The female patients who complained were simply accused of making it up. But the medical profession slowly had to revise its stance. Indeed, it is notable that several striking instances occurred where psychiatrists were publicly repudiated by the authorities. Among such cases, Georgina Weldon succeeded in having the unlawfulness of her confinement recognised, Edith Lanchester left the asylum, while the extraordinary Ann Pratt somehow managed from the other end of the Empire (Kingston, Jamaica) to initiate an administrative enquiry into the whole colonial asylum system ${ }^{66}$. More impressive still, the 1864 Act was abandoned in 1886, following women's concerted pressure, while in 1890, the Asylum Law was modified by the government in accordance with Louisa Lowe's recommendations: these changes stand as weighty indications of the influence women patients had by then achieved in the public sphere. As the century closed, it was clear that if psychiatrists wanted to stop being continually challenged, they had to take a step in the direction of their women patients. Doctor Forbes Winslow ${ }^{67}$ probably offers the most spectacular example in this respect. After being dragged through the courts for having agreed to intern Georgina Weldon at her husband's request without even having seen her, Winslow then performed a radical U-turn: he began by personally apologising to Weldon, then

provoke madness (a story inspired by her own experience). For the bonds and reciprocal inspiration between Perkins Gilman and Jacobi, see Bittel 2009.

66 Following a seven-month confinement, Ann Pratt, a simple "mulatto" woman, circulated throughout Kingston a pamphlet describing the cases of torture she had witnessed while in an asylum (Pratt 1860). This prompted a local enquiry in 1861, then an investigation across the Empire in 1883 (Jones 2008).

67 Lyttelton Stewart Forbes Winslow (1844-1913), who had taken on his psychiatrist father's clinic, became famous following the Weldon affair, but will be remembered by posterity for having investigated the case of Jack the Ripper, in whose crimes he showed so great a interest that he himself was suspected of being the murderer. 
moved to become her close friend. Finally, he went so far as to pen the preface of a book by Marcia Hamilcar ${ }^{68}$, another woman to have suffered at the hand of psychiatry.

Even if Winslow's example is somewhat extreme, it is nonetheless true that from the 1890s on, the entire medical world began to adopt a far more prudent attitude towards women. Together with the repeated anti-psychiatrist campaigns, such an evolution in medical thinking was furthered by the fact that increasing numbers of doctors began to encounter colleagues who were female. For, as several doctors were to remark during the annual meeting of the MedicoPsychological Association in 1893, the women present had not only succeeded in their medical studies, but had proved themselves to be excellent practitioners, all without any signs of degeneration ${ }^{69}$. It had thus become necessary to face up to the evidence: the female brain was undoubtedly not quite as feeble as had been thought and there was probably no clear evidence to suggest that women could not undertake 'men's occupations'. Naturally, the change in thinking was not universally accepted. We have spoken of Maudsley's vexation, cut off in total silence; Crichton-Browne reiterated his convictions until death, while Almroth Wright ${ }^{70}$ (a biologist and partisan of traditional evolutionist psychology) became an anti-suffrage leader ${ }^{71}$. Nevertheless, it should perhaps be noted more firmly than has been done hitherto, that the increasingly extravagant comments of these men were prompted, to a large extent, by their perception that their colleagues had begun to think twice about female inferiority, as indeed the voting at the BMA and M-PA in 1893 and 1894 had demonstrated, together with the association's acceptance, while they were at it, of some forty women doctors. A few years later, Thomas Claye Shaw ${ }^{72}$, another well-known alienist, summed up the state of

68 Hamilcar 1910.

69 Anon. 1893: 598-602.

70 Almroth Wright (1861-1947) is known for having developed an anti-typhoid vaccination.

71 Wright 1913.

72 Thomas Claye Shaw (1841-1927) practised in various asylums (Colney Hatch, Leavesden, Banstead). In addition to a successful psycho-surgical experiment on 
mind of many doctors at that time, saying that they had to admit that the skilled achievements of women had caught them short; final proof that women had a "special psychology", had indeed been provided, a psychology of a particularly unpredictable and progressive nature and one which had to be entirely reconsidered ${ }^{73}$.

Studies of the relationship between psychiatry and women's history have often been conducted in an accusatory tone, with feminist researchers in particular stressing the employment of the socalled mind sciences to repressive ends, and some, such as Phyllis Chesler, going as far as to support judicial lawsuits against psychiatrists. But while such militant foregrounding of doctors' victimisation of women might be a useful and even necessary thread of historiography, it has nonetheless led to the eclipse of another side of the question: the way in which patients endeavoured, sometimes with success, to respond to those doctors. Thus in line with a history of science which at present stresses the interaction between lay and expert discourses, we have tried to show here that even psychiatric knowledge has not been impermeable to patient reaction: in Britain, women patients even managed to rock psychiatry's vision of the female mind. But we should not go so far as to reverse the equation; the British example is an exception. Moreover, even if women succeeded in challenging the theories of the weaker mind, this did not mark those theories' total disappearance: they remained the backdrop to representations of women. When the suffragettes launched their more militant movement at the beginning of the twentieth century, these ideas quickly returned as the common way of thinking. Women were treated as hysterics ${ }^{74}$, their behaviour was said to illustrate the imperfections of the female brain, and naturally, doctors were called on as backup. As a result, activists were interned and the order issued that in the event of hunger strikes, women should be force-fed in the same way as some of the insane had been. The episode illustrates yet

a general paralytic, he is recognised for his analyses of the links between crime and madness.

73 Claye Shaw 1908.

74 Wright 1912. 
again the collusion between psychiatry and the subjection of women. Yet here too the situation turned itself around. For not only were psychiatrists unhappy about being so openly requisitioned, they were confronted with fresh demonstrations of the gaps in their thinking. For if women were truly a weak and nervously fragile sex, how could they ever have succeeded in organising themselves and even holding the government to ransom? Acting on the obvious conclusions, some doctors at this point switched sides and supported the suffragettes ${ }^{75}$; thus, in short, certain psychiatrists became feminists, an unthinkable state of affairs thirty years earlier and one which brought an unexpected turnaround in the prolonged doctor/womanpatient exchanges. Once more, this particular feature of British history cannot be transposed. Nevertheless, it illustrates a further aspect of the link between feminism and psychiatry, in which medical excesses sometimes played a somewhat paradoxical role, serving as much to construct as to destroy the women's movement.

Translated by Jane Yeoman

\section{Bibliography}

\section{Sources primaires}

Anon., 1893, "Annual meeting of the Medico-Psychological Association of Great Britain and Ireland », Journal of Mental Science, 39, p. 588-602.

—, 1895, « Miss Lanchester's case », Western Mail, 1 November.

Barnes Robert, 1890, "On the correlations of the sexual functions and mental disorders of women », British Gynaecological Journal, 1, 6, p. 390-413, p. 416-430.

Butler Josephine Elizabeth Grey, 1896, Personal Reminiscences of a Great Crusade, London, H. Marshall \& Son.

75 As examples of this, Thomas Claye Shaw, who was by no means revolutionary in his ideas, challenged the diagnosis of madness (Claye Shaw 1913), while Charles Mansell Moullin (1851-1940) and Agnes Savill (1875-1964) criticised forcefeeding as being physical and mental torture (Savill, Mansell Moullin \& Horsley 1912). 
C.S.C. (Churchill Clementine), 1912, «Ought women not to be abolished altogether? ", Times, 30 March.

Claye Shaw Thomas, 1908, «The special psychology of women», The Lancet, vol. 171, n4418, 2 May, p. 1263-1267.

—, 1913, "Correspondence. The psychology of the militant suffragette », The Lancet, vol. $181, \mathrm{n}^{\circ} 4681,17$ May p. 1415.

Crichton-Browne James, 1879, « On the weight of the brain and its component parts in the insane », Brain, $\mathrm{n}^{\circ} 1$, p. $514-518, \mathrm{n}^{\circ} 2$, p. $42-67$.

-, 1884, Elementary Schools (Dr. Crichton-Browne's Report...), London, House of Commons/H. Hansard \& son.

- 1892, "The annual oration on sex in education », The British Medical Journal, 7 May, vol. 1, n¹636, p. 949-954.

(Gilman) Stetson Charlotte Perkins, 1892, "The yellow wall-paper. A story», The New England Magazine, vol. 11, n5, January.

Hamilcar Marcia, 1910, Legally Dead. Experiences During Seventeen Weeks' Detention in a Private Asylum, London, John Ouseley.

Lowe Louisa, 1874, The first report of the Lunacy Law Reform Association, London, Lunacy Law Reform Association.

- 1883, The Bastilles of England; or, the Lunacy Laws at Work, London, Crookenden \& Co.

Maudsley Henry, 1874, "Sex in mind and education », Fortnightly review, 15, p. 466483.

Pratt Ann, 1860, Seven months in the Kingston Lunatic Asylum, and What I Saw There, Kingston, George Henderson Savage \& Co.

Reade Charles, 1863, Hard Cash. A Matter-of-Fact Romance, London, Sampson Low, Son \& Marston.

Savill Agnes F., Mansell Moullin Charles \& Victor W. Horsley, 1912, « Preliminary report on the forcible feeding of suffrage prisoners », The Lancet, 24 August, vol. $180, \mathrm{n}^{\circ} 4643$, p. 549-551.

Skram Amalie, 1899, Professor Hieronimus, London/New York, John Lane.

Weldon Georgina, 1882, How I escaped the Mad Doctors, London, privately published.

Wilkinson James John Garth, 1870, The Forcible Introspection of Women for the Army and Navy by the Oligarchy Considered Physically, London.

Wright Almroth, 1912, "Suffrage fallacies: Sir Almroth Wright on militant hysteria », Times, 28 mars.

—, 1913, The Unexpurgated Case Against Women's Suffrage, London, Constable. 


\section{Sources secondaires}

Appignanesi Lisa, 2008, Mad, Bad and Sad. A History of Women and the Mind Doctors from 1800 to the Present, London, Virago.

Bennett Bridget, Nicholson Helen \& Roy Porter (eds) 2003, Women, Madness and Spiritualism, London, Routledge.

Bland Lucy, 1995, Banishing the Beast: English Feminism and Sexual Morality 18851914, London, Penguin.

Bittel Carla, 2009, Mary Putnam Jacobi and the Politics of Medicine in 19th-century America, Chapel Hill, University of North Carolina press.

Carminero-Santangelo Marta, 1998, The Madwoman Can't Speak. Or Why Insanity is not subversive, Ithaca, Cornell University Press.

Chesler Phyllis, 1975, Les Femmes et la folie, Paris, Payot (trans. of: Women and Madness, New York, Avon Books, 1972).

Chapireau François, 2007, «Évolution du recours à l'hospitalisation psychiatrique au $\mathrm{xx}^{\mathrm{e}}$ siècle ", in Magali Coldefy (ed.), La prise en charge de la santé mentale en France. Recueil d'études statistiques, Paris, La Documentation française, p. 127143.

Cixous Hélène \& Catherine Clément, 1975, La jeune née, Paris, Union générale d'éditions.

Fauvel Aude, 2005, 'Témoins aliénés et 'Bastilles modernes'. Une histoire politique, sociale et culturelle des asiles en France (1800-1914)', doctoral thesis supervised by Jacqueline Carroy, Paris, EHESS.

_, 2010, «Madness: a 'female malady'? Women and Psychiatric Institutionalisation in France », in Patrice Bourdelais \& John Chircop (ed.), Vulnerabilities, Social Inequalities and Health in perspective, Évora, Ediçoes Colibri, p. 61-75.

—, 2012, «Femmes violeuses et hommes bafoués. Sexe, crime et médecine dans la France du xix ${ }^{\mathrm{e}}$ siècle », in Jean-Jacques Lefrere \& Michel Pierssens (dir.). Crimes et délits, $15^{\mathrm{e}}$ colloque des Invalides, Tusson, Éditions du Lérot, p. 91-116.

Foucault Michel, 2003, Le pouvoir psychiatrique : cours au Collège de France, 19731974, Paris, Gallimard/Seuil.

Hervey Nicholas, 1986, «Advocacy or folly: The alleged lunatics' friend society, 1845-1863 », Medical History, 30, p. 245-275.

Hornstein Gail A., 2011, Bibliography of First-Person Narratives of Madness in English, $5^{\text {th }}$ edition, http://www.gailhorstein.com/works/htm

Jones Margaret, 2008, «The Most Cruel and Revolting Crimes. The treatment of the mentally ill in mid-19th -century Jamaica », Journal of Caribbean History, 42/2, p. 290-309. 
Kent Susan Kingsley, 1990, Sex and Suffrage in Britain 1860-1914, London, Routledge.

Laqueur Thomas, 2003, Solitary sex, a Cultural History of Masturbation, New York, Zone

Lanchester Elsa, 1983, Elsa Lanchester Herself, New York, St Martins Press.

Maines Rachel P., 1999, The Technology of Orgasm: «Hysteria », the Vibrator and Women's Sexual Satisfaction, London, Johns Hopkin University Press.

Mellett David J., 1981, «Bureaucracy and mental illness: the commissioners in lunacy 1845-1890 », Medical History, 25/3, p. 221-250.

Moscucci Ornella, 1990, The Science of Woman: Gynaecology and Gender in England, 1800-1929, Cambridge, Cambridge University Press.

Oppenheim Janet, 1991, 'Shattered Nerves': Doctors, Patients, and Depression in Victorian England, New York, Oxford University Press.

Owen Alex, 1989, The Darkened Room: Women, Power and Spiritualism in Late Victorian England, London, Virago.

Pick Daniel, 1989, Faces of Degeneration: a European Disorder, c.1848-c.1918, Cambridge, Cambridge University Press.

Scull Andrew T., 2004, «The insanity of place », History of Psychiatry, 15/4, p. $417-$ 436.

- 2006, «A chance to cut is a chance to cure. Sexual surgery for psychosis in three $19^{\text {th }}$-century societies », in The Insanity of Place / The Place of Insanity. Essays on the history of Psychiatry, London / New-York, Routledge, p. 150-171.

—, 2009, Hysteria: the Biography, Oxford, Oxford University Press.

Sheehan Elizabeth A., 1997, "Victorian Clitoridectomy », in Roger N. Lancaster \& Micaela Di Leonardo (eds), The Gender/Sexuality Reader: Culture, History, Political Economy, London, Routledge, p. 325-334.

Showalter Elaine, 1987, The Female Malady. Women, Madness and English Culture, 1830-1980, London, Virago.

Tomes Nancy, 1990, «Historical perspectives on women and health », in Rima Apple (ed.), Women, Health, and Medicine in America. A Historical Handbook, New York, Garland, p. 143-171.

—, 1994, «Feminist histories of psychiatry », in Mark S. Micale \& Roy Porter (eds), Discovering the History of Psychiatry, New York, Oxford University Press, p. 348-383.

Vertinsky Patricia Anne, 1990, The Eternally Wounded Woman: Women, Doctors and Exercise in the Late $19^{\text {th }}$ Century, Manchester, Manchester University Press. 
Walkowitz Judith R., 1980, Prostitution and Victorian society: Women, Class and the State, Cambridge, Cambridge University Press.

—, 1992, "Science and the Seance: transgressions of gender and genre", in City of Dreadful Delight: Narratives of Sexual Danger in Late-Victorian London, Chicago, University 